\title{
METAL CASTING
}

$V_{\text {ISION: }}$

TO BE THE PREFERRED

SUPPLIER OF NET OR

NEAR-NET SHAPE

METAL COMPONENTS

BEYOND THE YEAR

2000.

BEYOND 2000: A VISION FOR

THE AMERICAN METAL CASTING IIDUSTRY

CAST METALS COALITION

\section{INDUSTRY OF THE FUTURE}

$$
\text { DOE EE-99001703 E }
$$

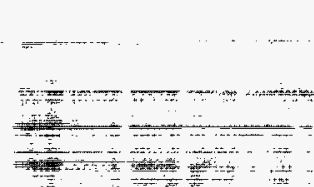

$=$<smiles>C1CCCCC1</smiles>
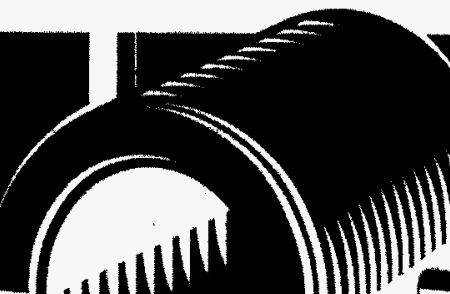
(ilin)

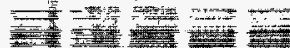

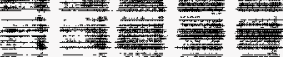

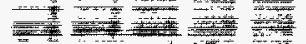

$\div-\ldots$

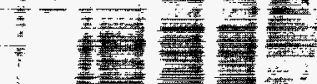

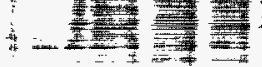

$+$

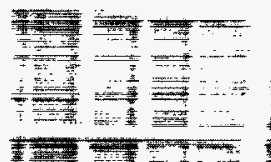

整

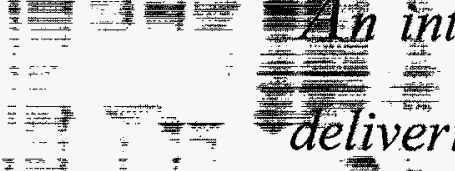

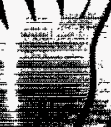
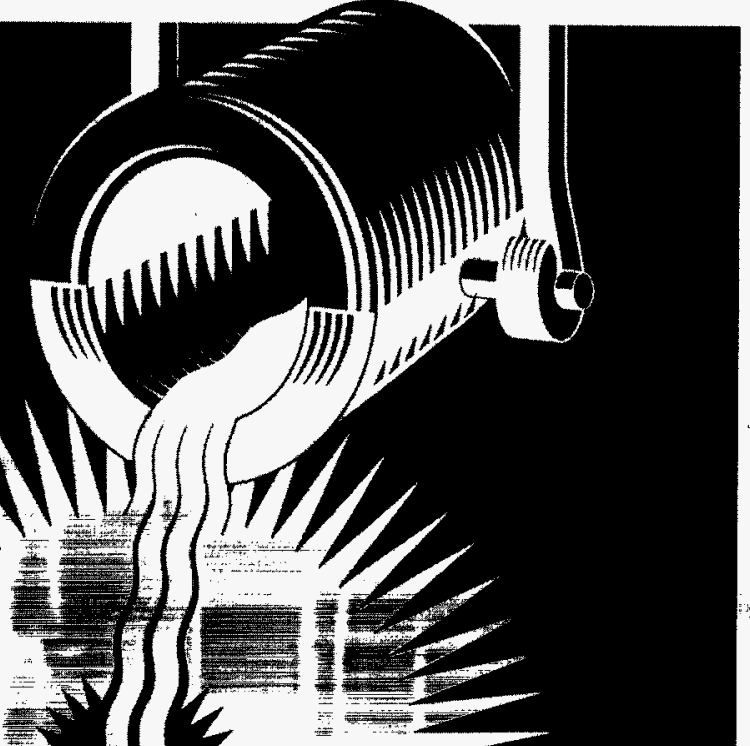

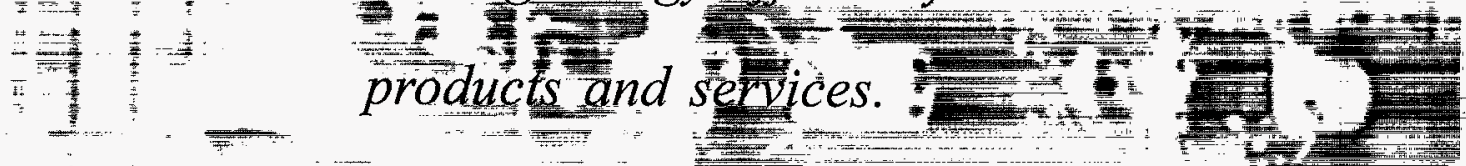

energy efficiency
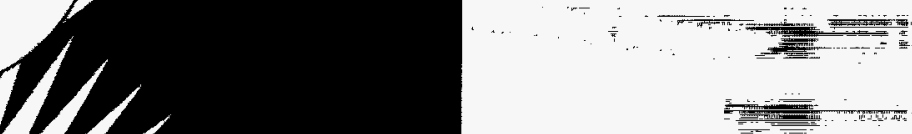

$1+$ prodickand solices.

$1+$ prodickand solices.

W

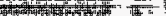

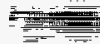

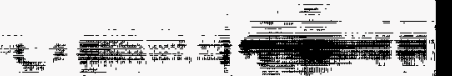

and

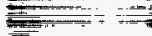

$=$

to

蛪

$\sum_{i=1}$

裳

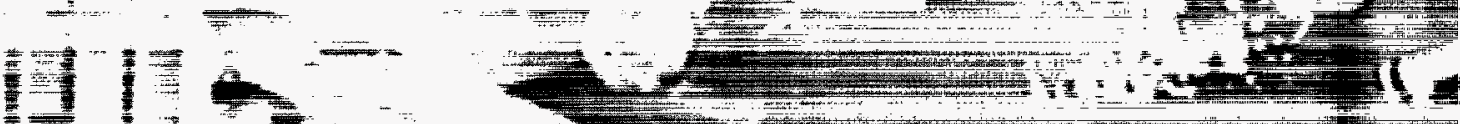

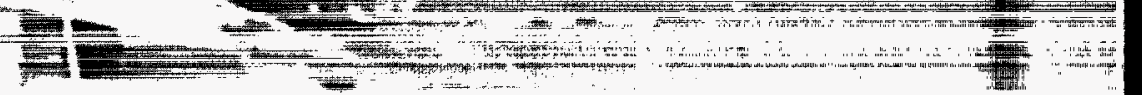

$$
\frac{15}{1+2}=1
$$

DISTRIBUTICN OF THIS DOCUMENT IS LARLATED \&

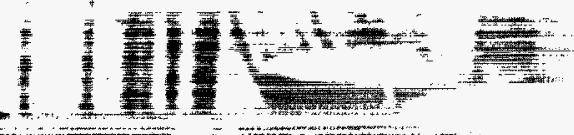
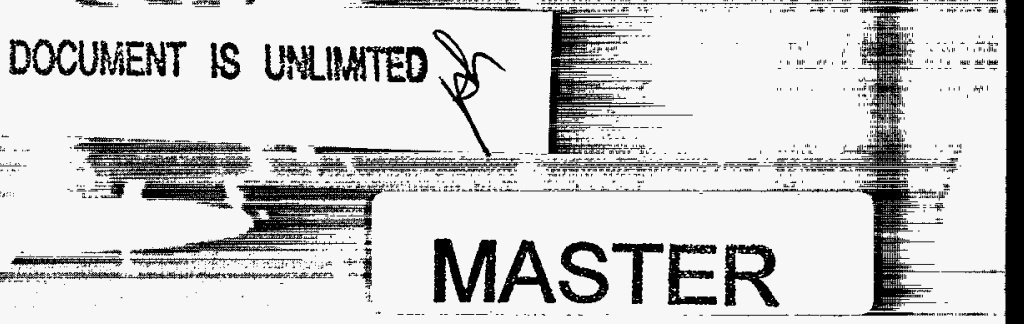

$=$ . 


\section{Partnering for a Clean and Competitive Industry of the Future}

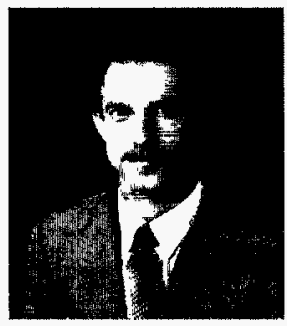

DAN W. REICHER Assistant SECRETARY ENERGY EFFICIENCY AND Renewable Energy
Our nation's strength is based in large part on our access to affordable and reliable energy. As we move into the new millennium, our mission is to develop and deploy new ways to meet our energy needs and improve our environmental qualify through use of renewable energy and increased energy efficiency.

Through the Industries of the Future Program, the Office of Energy Efficiency and Renewable Energy is actively engaged with U.S. industry to capture energy and natural resources savings by developing and deploying clean and energy efficient technologies and practices. Working with the nation's most energy intensive industries, we are mapping a vision of the energy future of American industry and developing the technology needed to implement that vision. This profile describes a few of the many ways that the DOE-industry alliance is working towards a more competitive future for U.S. industry and our nation.

\section{METAL CASTING:}

\section{FROM VISION...TO ACTION}

The Industries of the Future process is driven by industry. Through technology roadmaps, industry participants set technology priorities, assess the progress of $R \& D$, and ultimately lead the way in applying research results. This approach to private-public partnerships ensures the most strategic allocation possible of limited resources for the development of new technologies and the enhancement of industrial processes.

Based on industry's request, OIT's role is to help facilitate the Industries of the Future strategy and to support the development and deployment of technologies that will shape the future of the metal casting industry. Part of this role is to encourage industry to undertake long-term, sector-wide technology planning and to selectively cost-share with OIT in collaborative R\&D activities that match OIT's mission. OIT metal casting research requires a dollar for dollar industry cost share.

\section{THE VISION}

\section{Beyond 2000 initiates public-private collabo-} ration to address research challenges facing the U.S. metal casting industry

Metal casting processes are integral to virtually all U.S. manufacturing activities. In the U.S., castings are used to produce 90 percent of all manufactured durable goods and nearly all manufacturing machinery. The industry is composed of 2,950 foundries manufacturing diverse products. It is a small business industry with 80 percent of foundries employing less than 100 people.

Metal casting industry leaders have teamed with the U.S. Department of Energy's (DOE) Office of Industrial Technologies (OIT) to focus on high priority research and development (R\&D) needs and to accelerate the development and use of critical new technologies. Through this strategy, the industry intends to be the "preferred supplier of net-or near-net-shape metal components". The industry-government partnership is addressing the challenges that the industry and the nation will face in the 21 st century. This team is simultaneously advancing key national objectives in energy efficiency, the environment and competitiveness.

\section{Partnerships for the Future}

In Beyond 2000: A Vision for the Metal Casting Industry, industry leaders and technical societies developed a vision for the metal casting industry: The Vision lays the foundation for the partnership by identifying industry goals for being:

- Globally competitive

- Environmeñtally responsible

Well capitalized and profitable

- wrouce o challenging and we l-paying careers

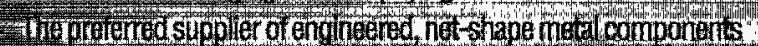

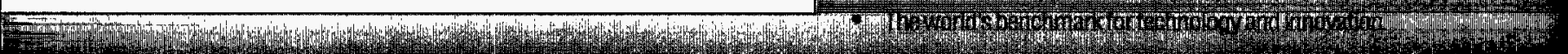

\section{STEP 1:}

VISION

Beyond 2000: A Vision for the

Metal Casting Industry defines the

20-year vision for the industry. It

was developed by and for industry.

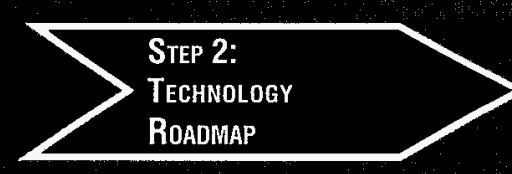

The Metal Casting Industry Technology Roadmap outlines R\&D pathways to achieve the goals set forth in the Vision.

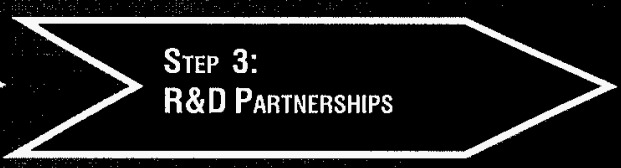

Enhanced

Gompetitiveness
The Cast Metals Coalition sponsors cost-shared research to address the performance targets set forth in the Roadmap. 


\section{DISCLAIMER}

This report was prepared as an account of work sponsored by an agency of the United States Government. Neither the United States Government nor any agency thereof, nor any of their employees, makes any warranty, express or implied, or assumes any legal liability or responsibility for the accuracy, completeness, or usefulness of any information, apparatus, product, or process disclosed, or represents that its use would not infringe privately owned rights. Refereace herein to any specific commercial product, process, or service by trade name, trademark, inanufacturer, or otherwise does not necessarily constitute or imply its endorsemeat, recommendation, of favoring by the United States Government or any agency thereof. The views and opinions of authors expressed herein do not necessarily state or reflect those of the United States Goverament or any agency thereof. 


\section{DISCLAIMER}

Portions of this document may be illegible in electronic image products. Images are produced from the best available original document. 


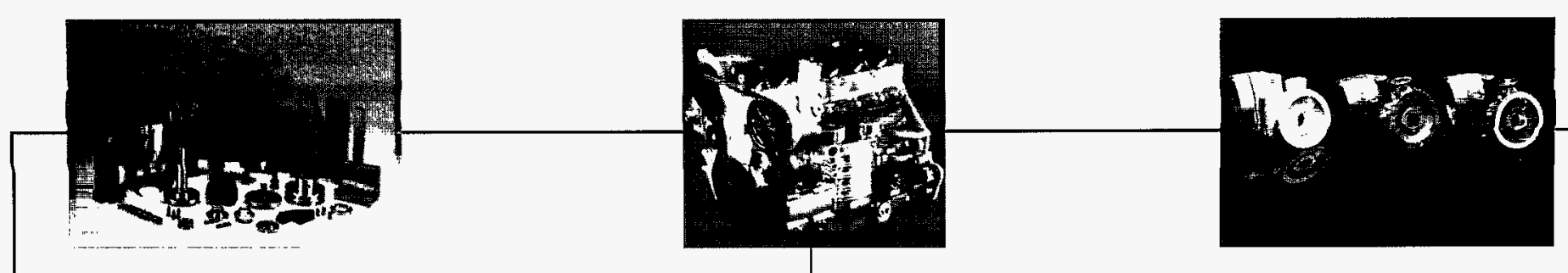

\section{THE ROADMAP}

\section{METAL CASTING INDUSTRY OF THE FUTURE}

\section{Metal Casting Industry defines research priorities and performance targets}

The Metal Casting Industry Technology Roadmap was developed through a workshop of experts from the metal casting industry, academia, technical societies and National Laboratories. These experts identified industry opportunity, technology barriers, priority research needs and specific performance targets for the industry. The Roadmap outlines pathways of near-term, mid-term, and long-term research activities in four critical areas: Products and Markets; Materials Technologies; Manufacturing Technologies; and Environmental Technologies. The Roadmap discusses industry challenges in education and training, attracting and building quality personnel, increasing foreign competition, responding to regulatory requirements, and continuing effective partnerships and collaborations.

The Cast Metals Coalition uses the Roadmapas the foundation for soliciting and selecting research proposals cost-shared between industry and the Office of Industrial Technologies.

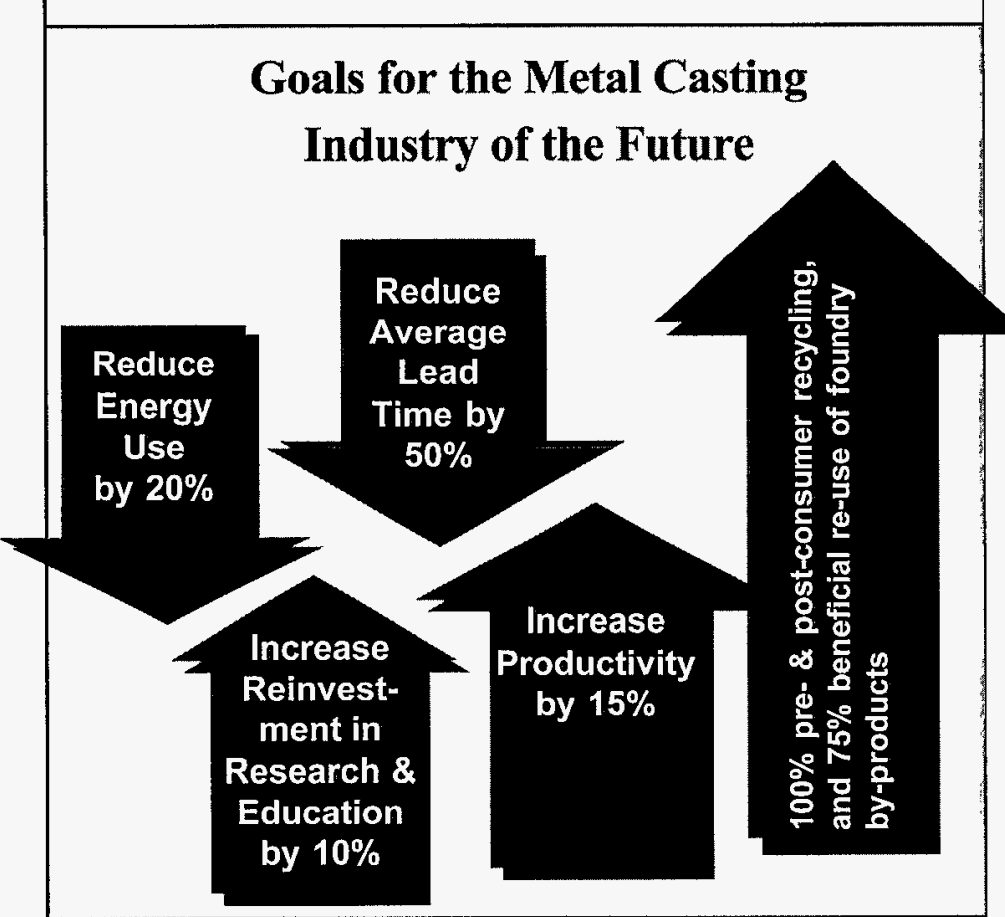

Led by the Cast Metals Coalition (CMC), the Metal Casting

Industry of the Future is conducting research to address Vision and Roadmap goals. The CMC is composed of the American

Foundrymen's Society, the North American Diecasting Association and the Steel Founders' Society of America.

\section{Selected high priority research needs}

The Roadmap identified priority research needs in four key areas:

\section{Materials Technology}

Metallurgical breakthroughs will lead to the development of new materials that are more readily manufactured and environmentally friendly. High priority research needs include:

- Develop quantitative relationships between alloy chemistries, properties and processing.

- Establish standard methodologies for materials testing.

- Improve clean melting and remelting.

- Improve techniques to measure melt quality prior to casting.

\section{Manufacturing Technology}

Continued progress in advanced design and manufacturing technologies is critical to industry competitiveness. High priority research needs include:

- Developing low-cost rapid tooling technology.

- Developing smart controls and sensors.

- Developing melting and pouring technologies that maintain melt quality.

- Developing modeling tools to improve quality through process control.

\section{Products and Markets}

New processes are needed to cast metal components that meet demanding material and design specifications. High priority research needs include:

- Developing computer design tools to move from design concept to design for manufacturing.

- Demonstrating the quality and value of castings.

- Transforming foundries to tier-one suppliers.

\section{EnVIRONMENTAL TECHNOLOGIES}

Waste recycling and re-use has always been integral in the industry. Continued emphasis is being placed on:

- Environmental sound, dimensionally stable molding materials for sand casting.

- New uses for waste streams and new waste treatment methods.

\section{Addressing future developments}

The Metal Casting Industry Technology Roadmap will be revised and updated periodically to reflect changing market and technical issues and to ensure that research priorities remain relevant to customer needs. 


\section{PORTFOLIO HIGHLIGHTS}

\section{Industry of the Future projects advance metal casting vision}

The Metal Casting Industry of the Future's portfolio includes over 50 past and current research projects. The portfolio demonstrates the Program's and the partnership's commitment to addressing the diverse needs of the casting industry. It also demonstrates its commitment to industry collaboration, education and the future competitiveness of the industry.

The vast majority of this research is performed by researchers, educators and students from over 20 universities and laboratories. During its history, over 250 industry partners from more than 30 states have provided critical technical and cost share support. Many are small companies. They represent the diversity of the industry - utilizing a range of casting processes and supplying cast products to an array of casting markets. The Metal Casting Industry of the Future strategy is enabling the industry to secure the technical and human resources needed to compete in future metal casting markets.
The following pages provide samples of Metal Casting Industry of the Future research projects.

Unconventional Methods for Yield Improvement in Steel Foundries

Key variables impacting yield in steel casting have been identified and both conventional and novel yield improvement techniques are being developed. These techniques should allow castings to be produced with a $10 \%$ to $25 \%$ higher yield. Improved casting yield will lead to significant energy savings in the melting phase of steel casting production.

\section{Partners}

Steel Founders' Society of America

University of lowa

Over 39 U.S. Foundries

\section{Mechanical Properties of Lead-free Copper-base Engineering Alloys in Permanent Molds}

Permanent molds of copper-base alloys offer a better surface finish, precise and dimensional control and improved mechanical properties. This research is identifying minimum mechanical properties, fracture toughness and fatigue properties of seven alloys.

Partners

AB Chance Company

American Foundrymen's Society

Bunting Bearing Corporation

H. Kramer \& Company

Materials Technology Laboratory

Starline Manufacturing Co., Inc.

\section{Research Sites for Metal Casting Industry of the Future R\&D Projects}

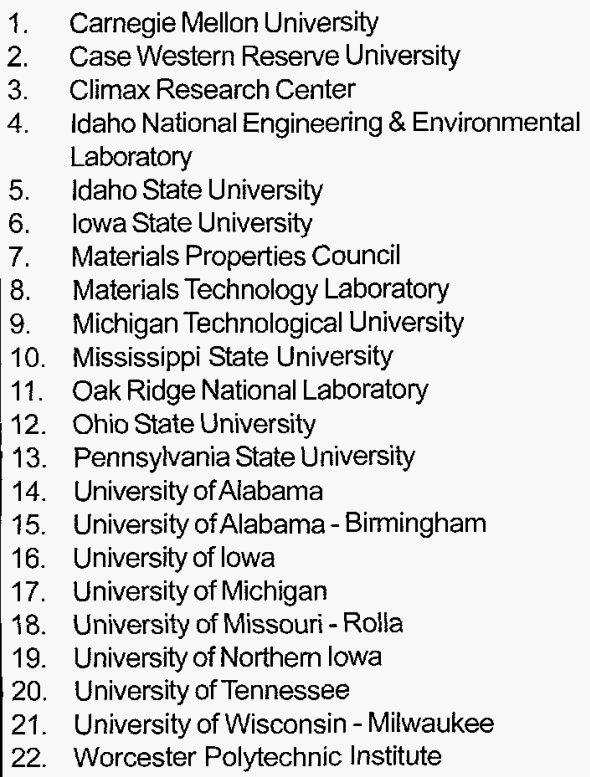

- Represents industry partners.

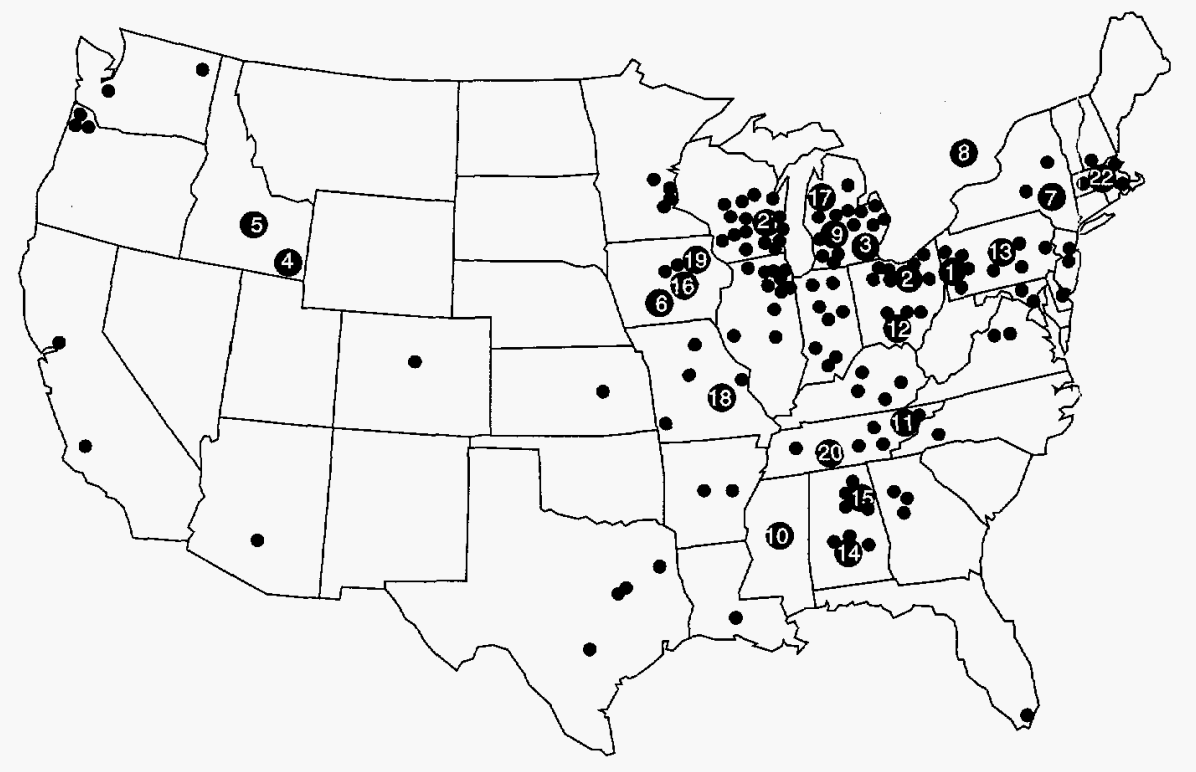




\section{Macro-Inclusions Atlas:}

\section{Website Assists Foundries Analyze Macro-inclusions} contribute to the reduced in-service life of cast components and result in component remanufacturing. The Macro-inclusions Atlas provides foundries with access to data they can apply on a real-time basis to reduce the frequency of macro-inclusions and reduce energy consumption. The Atlas is available to the public at http://neon.mems.cmu.edu/afs/atlas.html.

\section{Partners}

American Foundrymen's Society

Carnegie Mellon University

Eagle Alloy

Minteq International, Inc.

Nupro Corporation

Process Metallurgy International, Inc.

Taussig

\section{Semi-Solid Metals Processing Consortium}

This project is leading to the development of improved alloys for SSM, a better understanding of thixotropic flow behavior, and a properties database. Increased use of the SSM process will lead to reduced on-site energy use due to lower temperature requirements. It will also enable production of lower-weight, higher strength cast components.

\section{Partners}

North American Die Casting Association

Worcester Polytechnic University

Over 20 industry partners

\section{Clean Cast Steel}

This project is identifying measures that lead to improved cast product quality by removing or minimizing oxide defects that require weld repair. Participating foundries have seen significant improvement in reducing dirt and in the number of welds requiring repair. This is leading to considerable energy savings in the post-processing phase of metal casting.

\section{Partners}

University of Alabama - Birmingham

Steel Founders' Society of America

Over 20 industry partners

\section{Visualization Tools for Die Casting Part and Die Design}

CastView software provides a qualitative method for visualizing die casting design problems early in the die casting process. It minimizes flow related filling problems, thermal problems in the die, and solidification-related defects in the cast part. Reducing the number of design trials on the shop floor will reduce both on-site energy use and scrap rates.

\section{Partners}

North American Die Casting Association

Ohio State University

Over 10 industry partners
Macro-inclusions are a major factor in the rejection of castings,

\section{Case Studies}

Advanced Intelligent Control Methods Applted to the Cupola Melter

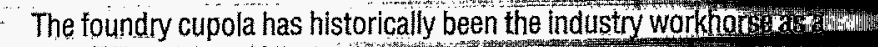
low-cost technology for melting lron. Research at the Albany Research Center is advancing control methods for the cupolatwing enabling industry to meet new environmental regulations whine continuing to utilize the low-cost melting technology.

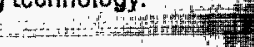

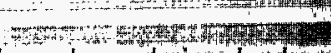

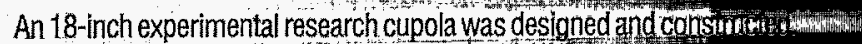

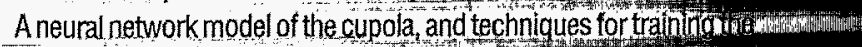
neural network, were developed. Testing has demonstrajed the teas ibitwitum using automatic control methods in cupola operations.

\section{Potential Benefits}

- Energy savings of 400 million Btu per year per uni

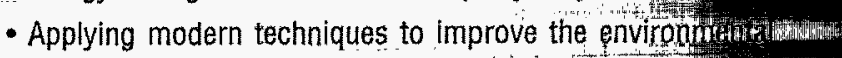

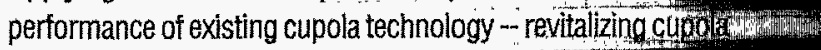
operations in the U.S. and enhancing U.S. Soundry Industry competitiveness

- Decreased coke requir..........

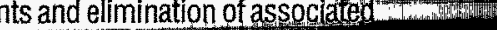
emissions.

\section{Lost Foam Casting}

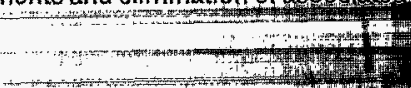$$
\text { sing }
$$

Lost foam casting allows designers to consolidate parts reduce

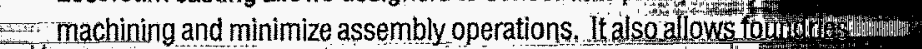

- 5 to reduce solid waste and emissions. Researchat the Universitu o Alabama - Birmingham is leading to a greater understanding of wha nos

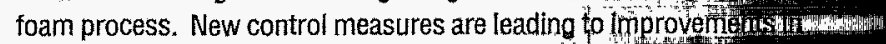
each stage of the process. They include a non-contact air galug density gauge, and vibrational analysis instrumentation

\section{Potential Benefits}

and

- Higher quality castings and dramatic reductions In sctor

- More cost-and energy-efficient foundry operations

- Breakthrough technology for producing components by elipina ing w winlin

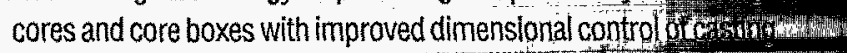

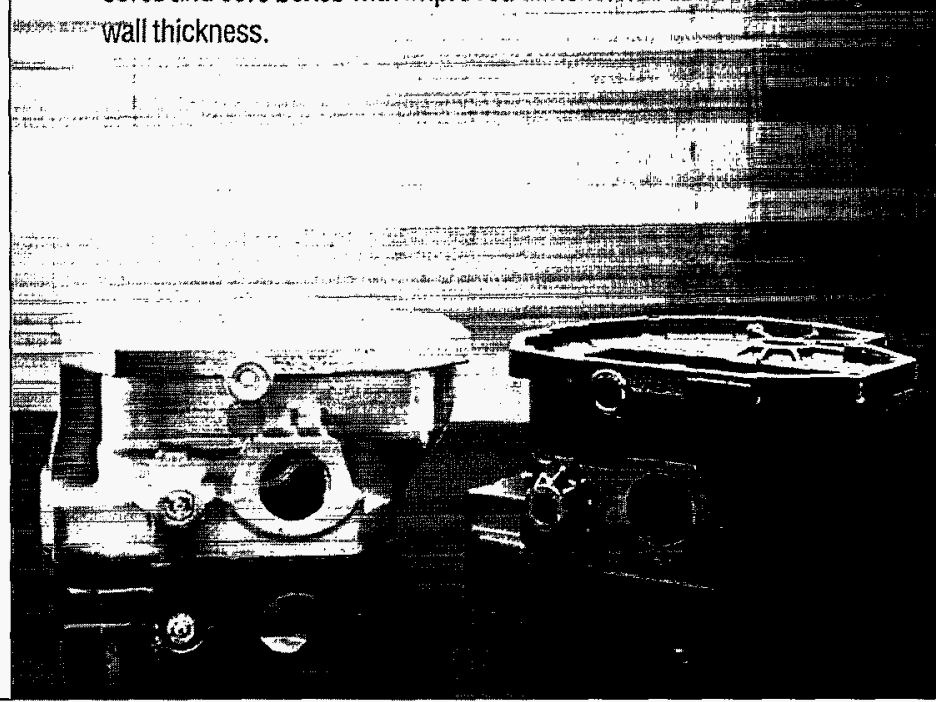

For information on other projects in the Metal Casting portfolio, contact the DOE Metal Casting Program Manager, or contact the sponsoring technical societies. These are the American Foundrymen's Society, North American Die Casting Association and the Steel Founders' Society of America. 


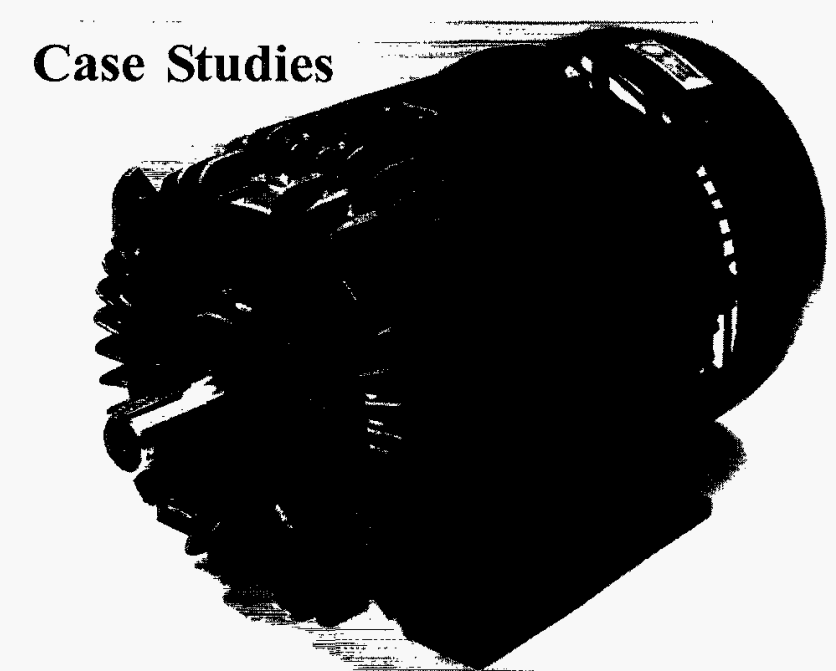

NICE ${ }^{3}$ Program: Usiñgfigh Temperature Materials to Die Cast Copper Motor Rotors Efficiently

Though it conducts electricity less efficiently than copper, aluminum is preferred for manufacturing conductors in electric induction motor rotors because it can be die cast relatively easily. The goals of this project, sponsored by the OIT NICE ${ }^{3}$ Program, are to design, fabricate, and demonstrate molds that will withstand the copper motor rotor die casting environment for an economically-acceptable life of 1,000 or more cycles. Using an innovative chemical vapor composites material-forming process, ThermoTrex will demonstrate that tungsten and molybdenum can be used to manufacture cost- and energy-efficient casting molds. By developing motor rotor molds that can withstand the high temperatures needed for die casting copper, this project will enable motor manufacturers to produce more efficient electrical motors that use less electricity.

\section{Potential Benefit}

- Improved motor efficiency and decreased energy requirements compared to aluminum motor rotors.

- Reduced emissions of greenhouse gases

\section{Inventions \& Innovations: Innovative Refractory Filtering Cloth to Remove Impurities from Molten Metals}

With support from the Inventions and Innovations Program, Jay R. Hitching \& Son, Incorporated is developing an automated means of filtering slag, dross, and other non-metallic impurities from molten metals in the process of casting metal parts on injection molding machines.

A refractory filter cloth, tightly woven from material such as metal wire, glass fiber, or ceramic fiber is automatically advanced between injection shot of the molding or casting machine. The filter is clamped in place and sealed by the inventor's apparatus during each injection shot of molten metal. It is then moved forward for the next injection shot so that a clean portion of the filter can be used each time.

\section{Potential Benefits}

- Reduction of impurities and defects in castings.

- Higher quality castings and higher productivity.

\section{RESEARCH, SERVICES AND RESOURCES}

\section{DOE programs support Metal Casting Industry of the Future}

\section{OIT'S Industries of the Future strategy accelerates} $R \& D$ of novel technologies of interest to nine energy-intensive industries: aluminum, chemicals, forest products, glass, metal casting, mining, petroleum refining, agriculture, and steel. The strategy is sponsored and facilitated by OIT, a unit of DOE's Office of Energy Efficiency and Renewable Energy. Focus is on high-risk, high-payoff precompetitive research over a 20-year time frame.

A key element of the Industry of the Future strategy is Integrated Delivery. OIT offers a range of programs that can help the metal casting industry save energy, reduce costs, and cut pollution. Through this Integrated Delivery of energy efficiency products and services, industry has streamlined access to the resources and capabilities of the National Laboratories and other Federal programs. OIT staff focus on delivering the technologies, tools and expertise from OIT's portfolio that provide the right services to meet the customer's needs. Laboratory access is facilitated by the Laboratory Coordinating Council (www.oit.doe.gov/lcc/lccintro.html), which produces detailed documentation of current and past research projects and laboratory capabilities that correspond to metal casting technology needs. OIT's Industrial Projects Locator (www.oit.doe.gov/ locator), provides industry with information on all recent Federally-funded research activities related to metal casting.

\section{Technology for Today ... Technology for the Future}

\section{Enabling Technologies}

AlM (Advanced Industrial Materials) develops and commercializes new and improved materials to increase energy efficiency, improve productivity, and enhance material longevity and product quality.

The Combustion program increases productivity, improves energy efficiency, reduces emissions, and enhances fuel flexibility by developing cost-effective and energy-efficient technologies that are necessary for global competitiveness.

Continuous Fiber Ceramic Composite Materials pursues ceramic composite technologies that improve productivity by utilizing higher process temperatures, extending component and system lifetimes, and reducing downtime.

Sensors \& Controls develops and deploys integrated measurement systems for operator-independent control of the manufacturing process. Priority goals are improving technology both in sensors embedded in high temperatures and harsh environmental applications, and in information processing to detect and remedy malfunctions. 


\section{Distributed Generation Technologies}

Cogeneration improves the efficiency of fuel use and reduces overall emissions. This program supports extensive research, development, and demonstration to meet the technical and market challenges associated with enhancing industrial cogeneration and moderate-size independent power production opportunities.

\section{Financial Assistance}

The Inventions \& Innovation program provides financial assistance for establishing technical performance and conducting early development of innovative ideas and inventions. Ideas with potential for significant energy savings and commercial use are chosen for financial support through a competitive solicitation process. Technical guidance and commercialization support are offered to successful applicants.

\section{NICE $^{3}$ (National Industrial Competitiveness Through Energy,} Environment, Economics) is an innovative cost-sharing program that promotes energy efficiency, clean production, and economic competitiveness in industry by providing funding to State and industry partnerships for technology demonstration projects.

\section{Technical Assistance}

Combined Heat \& Power Challenge is focused on overcoming major barriers that currently exist in implementing combined heat and power systems, including complex and costly environmental permitting, unclear environmental regulations, excessive utility fees and rates, and long and varied Federal tax depreciation schedules.

Compressed Air Challenge is dedicated to improving the efficiency and performance of industrial compressed air systems with the goal of reducing energy use and costs.

IACs (Industrial Assessment Centers) help small and medium-size manufacturers identify opportunities to improve productivity, reduce waste, and save energy through comprehensive industrial assessments. Teams of engineering professors and students from 30 universities across the country conduct the assessments and provide recommendations to manufacturers at no cost.

Motor Challenge helps increase the productivity and reliability of electricmotor-driven systems, reduce energy costs, and improve the bottom line. IT provides reliable, unbiased information, tools, and technical assistance to improve motor system efficiency.

Steam Challenge provides information tools and technical assistance that can help industry enhance productivity, lower production costs, and reduce emissions of its industrial steam systems.

\section{Additional information resources include:}

IPLocator (www.oit.doe.gov/locator) provides access to information on federally sponsored $R \& D$ projects that are ongoing or recently completed, optimizing the complementary research and development strengths of industry, universities, National Laboratories, and government.

OIT's Resource Catalog, available by calling 202-586-2090, describes over 400 publications and other information products of interest to our customers.

\section{HOW TO GET INVOLVED}

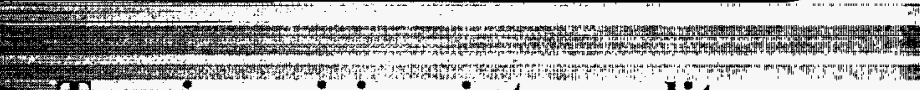
Turning vision into reality $=$ For For U.S. metal casting companies, Industry of the Future partnerships can bring clear competitive - advantages. Participating companies benefit from the reduced cost and risk of collaborative R\&D and - streamlined access to Federal scientific resources. - Positioned at the forefront of technology developTrient, these companies reap the benefits of more IVtficient and productive technologies and, in turn, - contribute to our Nation's energy efficiency, indus- Tralcompetitiveness, and environmental quality.

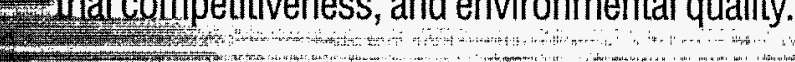
7 . Ways to participate

- By aligning $R \& D$ resources within industry and government to meet indus- typutoritfes, the Metal Casting Industry of the Future will be poised to - compete more effectively than ever before in global markets.

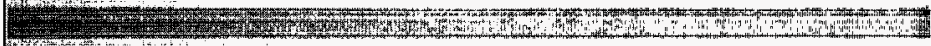
There are many ways to particlpate:

- Honitor our Web pages for news and announcements of R\&D Wut solicitations. Check the Metal Casting website at: www. oit.doe.00v/10F/ - Metalcasfand the Cast Metais Coalition website at: htop:ll - iniciatrore ord

- Ieamuithother organizations and respond to solicitations far - Cost-shared research issued by OIT's Metal Casting Industry of the - Future team, our Enabling Technologies programs, and our Financial 2. Is Istance programs. -2 Begin saving eneray, reducing costs and cutting pollution in yourpiant today by participating in any of the Technical-Assistance yaxpy programs.

- Call Marilyn Burgess, manager of OlT's Resource Room

(202-586-2090), to learn more about the listed activities and

\section{services.}

- Contact the olT Metal Casting Program Manager or the Members of the

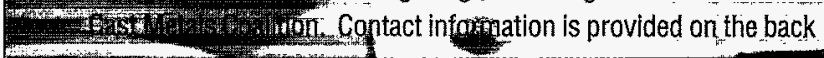

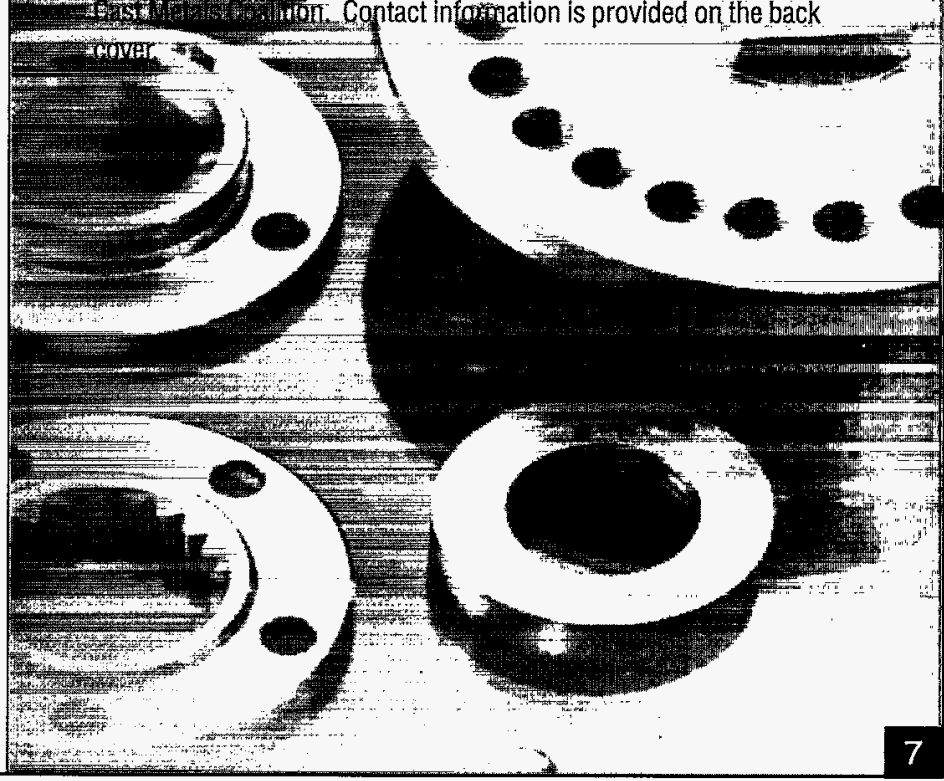

